\title{
Synthesis and Anodic Electrochemistry of Cymanquine and Related Complexes
}

\author{
Kevin Lam ${ }^{\mathrm{a}, \mathrm{b}}$ *, William E. Geiger ${ }^{\mathrm{a}, \text { * }}$ \\ ${ }^{a}$ Department of Chemistry, University of Vermont, Burlington, VT 05405, U.S.A. \\ ${ }^{\mathrm{b}}$ Department of Chemistry, School of Science and Technology, Nazarbayev University, \\ Astana, Republic of Kazakhstan, 010000 \\ Cymanquine_JOMC_Revised.docx
}

\begin{abstract}
Three compounds have been prepared in which a 4-aminochloroquinoline moiety is covalently linked to a cyclopentadienyl manganese tricarbonyl moiety. One of these ("cymanquine", 4) is the analogue of the potent antimalarial drug ferroquine in which an FeCp group has been replaced by a $\mathrm{Mn}(\mathrm{CO})_{3}$ group. The anodic electrochemistry of the new compounds was investigated in dichloromethane, using $\left[\mathrm{NBu}_{4}\right]\left[\mathrm{B}\left(\mathrm{C}_{6} \mathrm{~F}_{5}\right)_{4}\right]$ as the supporting electrolyte. Compared to ferroquine, oxidations of the new compounds occur at considerably more positive potentials and are highly irreversible, being located at their amine groups rather than at the organometallic center.
\end{abstract}

\section{KEYWORDS}

Bioorganometallic; cymantrene; ferroquine; chloroquinoline; anodic oxidation; weakly coordinating anion

\section{HIGHLIGHTS}

- "Cymanquine", the $\mathrm{CpMn}(\mathrm{CO})_{3}$ analogue of ferroquine, has been prepared

- Anodic electrochemistry of cymanquine was recorded in a $\left[\mathrm{B}\left(\mathrm{C}_{6} \mathrm{~F}_{5}\right)_{4}\right]^{-}$- based electrolyte

- The anodic oxidations of cymanquine are irreversible and involve its tertiary and secondary amines

Emails: kevin.lam@nu.edu.kz_william.geiger@uvm.edu

\section{Introduction}

A leading strategy in the expanding field of bioorganometallic chemistry [1 - 4] is the synthesis of hybrid compounds composed of covalently linked conjugate pairs of separately recognizable organic and organometallic $(\mathrm{OM})$ moieties. The organic scaffold may have already identified medicinal properties. An OM bioconjugate is added with the goal of changing those properties in predictable ways or to provide the system with an electrochemical or spectroscopic analytical 'tag' $[4,5]$. 
Although a ferrocenyl group has been the most frequently-utilized OM conjugate [6], other moieties are being increasingly investigated, especially for the purpose of employing metalcarbonyl IR absorptions as analytical markers [7, 8]. Among the most promising non-ferrocenyl OM bioconjugates are the strongly IR-active Group 7 'piano-stool' moieties $\mathrm{M}(\mathrm{CO})_{3}\left(\eta^{5}-\mathrm{C}_{5} \mathrm{H}_{4} \mathrm{R}\right)$, which have been termed cymantrene and cyrhetrene, when $M=M n$ and $M=R e$, respectively, and $\mathrm{R}=\mathrm{H}[9-16]$.

Described in the present paper are compounds in which the five-membered rings of cyclopentadienyl $(\mathrm{Cp})$ manganese tricarbonyl moieties have been covalently linked to the endocyclic nitrogens of 4-aminoquinolines. The interests of ourselves and others $[9,17]$ in conjugates of this general class has its origin in the fact that the organic scaffold is based on chloroquine $(\mathrm{CQ}, \mathbf{1})$ which, along with hydroxychloroquine $(\mathrm{HCQ}, 2)$ finds use in the treatment of human diseases, including malaria [18,19] and rheumatoid arthritis [20,21]. However, the efficacy of CQ and HCQ as antimalarial drugs has been compromised by the fact that parasites such as Plasmodium falciparum have developed resistance to them [22-24]. One of the most promising new antimalarial agents to which $P$. falciparum strains are not resistant is the hybrid compound "ferroquine" (FQ, 3), in which an alkylamine-substituted ferrocenyl group is linked to a CQ-like backbone [25-31]. Herein is reported the first preparation of the cymantrene analogue of FQ, which we term cymanquine $(\mathrm{CMQ}, 4)$ by analogy with its ferrocenyl predecessor. Two other closely related new manganese tricarbonyl compounds ( 5 and $\mathbf{6}$ ) were also prepared.

One of the most important and widely studied properties of ferrocene derivatives is their anodic electrochemical behavior. Owing to the propensity of a ferrocenyl group to undergo a relatively facile one-electron oxidation, the question of possible involvement of ferrocene/ferrocenium redox chemistry in the medicinal activity of FQ has arisen $[32,33]$. Cymantrene and $\mathrm{Cp}$-substituted cymantrenes also exhibit one-electron oxidations, giving radical cations that are stable under controlled conditions [34]. Characterization of the anodic electrochemistry of compounds 4-6 is therefore relevant to both their general characterization and any mechanism of action in their possible biological activity [35]. Thus, information about the potentials and degrees of chemical reversibility of the anodic oxidations of these compounds are reported herein. 

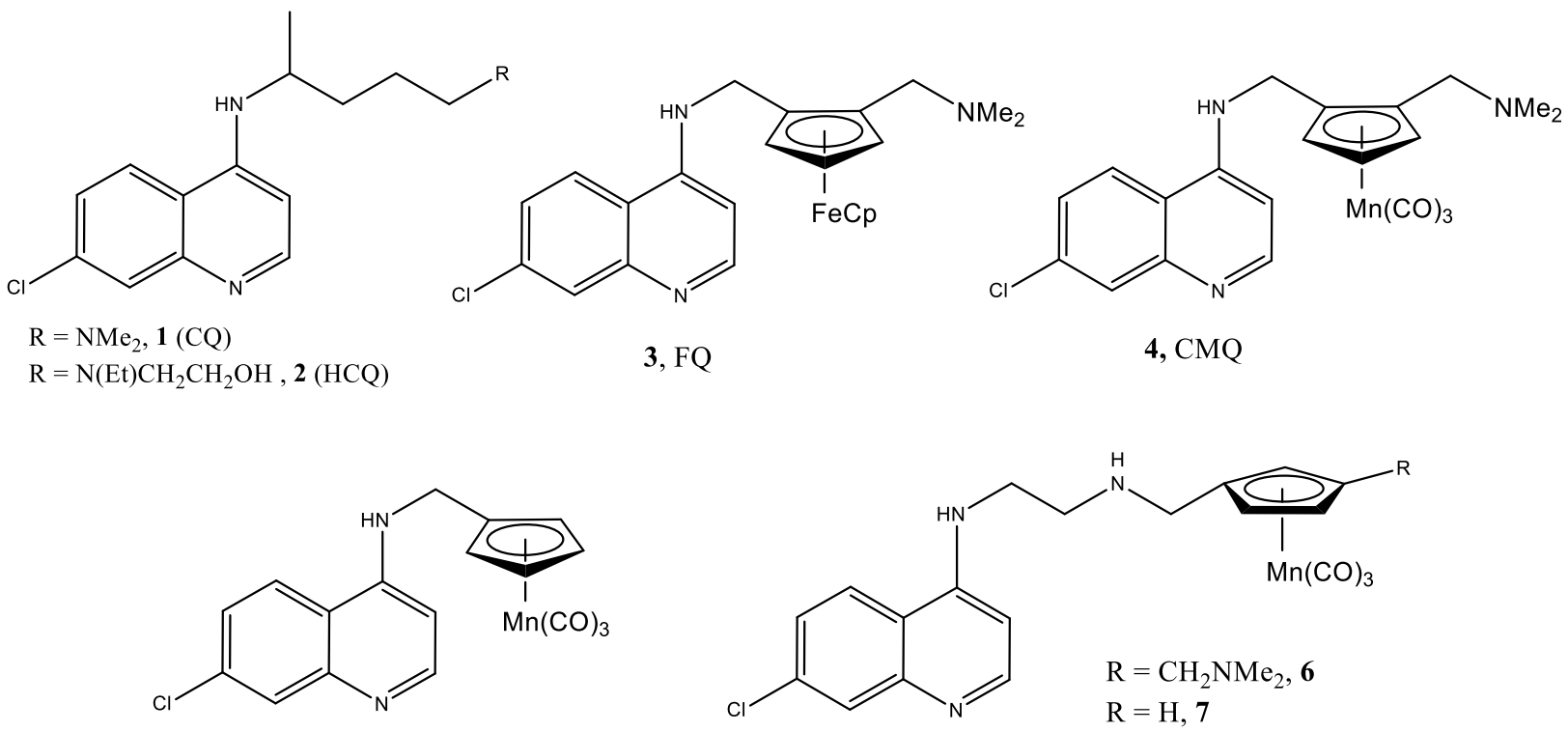

5

\section{Experimental}

\subsection{Materials}

Chemical reactions and electrochemical studies were conducted under a nitrogen atmosphere. The former were performed under standard Schlenk conditions and the latter were performed in a Vacuum Atmospheres drybox under oxygen levels of less than $5 \mathrm{ppm}$. Solvents were purified by sending them through an alumina column. Cymantrene was purchased from Molekula $\mathrm{GmbH}-$ Germany. Other reagents were purchased from Acros Organic or Sigma Aldrich and used as received. $\left[\mathrm{NBu}_{4}\right]\left[\mathrm{B}\left(\mathrm{C}_{6} \mathrm{~F}_{5}\right)_{4}\right]$ was prepared as previously described [36].

$\underline{\alpha-(7-c h l o r o q u i n o l i n-4-a m i n o})-\beta-(\mathrm{N}, \mathrm{N},-$ dimethylaminomethyl)cymantrene, cymanquine, $\mathrm{CMQ}$, 4. $\alpha$-Formyl-(N,N,-dimethylaminomethyl)cymantrene 11 [37] (1.12 g, $3.87 \mathrm{mmol})$ was dissolved in $40 \mathrm{~mL}$ of dry methanol at $273 \mathrm{~K}$. Sodium borohydride $(0.322 \mathrm{~g}, 8.52 \mathrm{mmol})$ was added by portion over 15 minutes and the solution was allowed to come back to room temperature. After 2 $\mathrm{h}$, most of the solvent was removed under reduced pressure and the mixture was dissolved in 30 $\mathrm{mL}$ dichloromethane. The solution was washed twice with $30 \mathrm{~mL}$ water, after which the organic layer was isolated, dried over magnesium sulfate, filtered, and the solvent removed under reduced pressure. $\alpha$-hydroxymethyl-(N,N,-dimethylaminomethyl)cymantrene $\mathbf{1 2}$ was obtained in a $67 \%$ yield as a dark brown oil sufficiently pure to be used in the next step. To a solution of 50 $\mathrm{mg}(0.172 \mathrm{mmol})$ of this compound in $1 \mathrm{~mL}$ dry THF were added phthalimide $(32.3 \mathrm{mg}, 0.22$ 
mmol) and triphenylphosphine (57.6 $\mathrm{mg}, 0.22 \mathrm{mmol})$. Then diisopropyl diazene-1,2dicarboxylate (DIAD) (47 uL, $0.22 \mathrm{mmol}$ ) was added. After $1 \mathrm{~h}$, the solvent was removed and replaced by $0.5 \mathrm{~mL}$ methanol. Hydrazine hydrate $(24 \mathrm{uL}, 0.32 \mathrm{mmol})$ was added to this solution, which was stirred at room temperature for $30 \mathrm{~min}$. After addition of $10 \mathrm{~mL}$ of a $1 \mathrm{~N}$ solution of $\mathrm{HCl}$, the solution was quickly extracted three times with $10 \mathrm{~mL}$ ethyl acetate. The $\mathrm{pH}$ of the aqueous layer was increased to 13 by addition of a solution of $1 \mathrm{~N} \mathrm{NaOH}$ and thrice extracted with $10 \mathrm{~mL}$ dichloromethane. The organic layers were combined, dried over magnesium sulfate, and the solvent removed under reduced pressure to yield $26.2 \mathrm{mg}$ of $\alpha$-aminomethyl-(N,N,dimethylaminomethyl)cymantrene 14, which was used directly in the next step. This sample (0.090 mmol) was dissolved in a $2 \mathrm{~mL}$ dry propanol solution containing 7-chloro-4fluoroquinoline $(17.2 \mathrm{mg}, 0.095 \mathrm{mmol})$ and refluxed overnight, after which the solvent was removed under reduced pressure and the compound purified by column chromatography over silica gel using AcOEt/Hexane (1:9) as the eluent. A light brown powder was obtained for CMQ 4 (12.4 mg, 16\% yield over the three steps from the hydroxyl compound), m.p. $171.5^{\circ}-172.5^{\circ}$. The solid did not seem to be overly air-sensitive. It was stored in the dark owing to the light sensitivity common among cymantrene derivatives. Calcd for $\mathrm{C}_{21} \mathrm{H}_{19} \mathrm{ClMnN}_{3} \mathrm{O}_{3}$ : C, 55.83; $\mathrm{H}$, 4.24; N, 9.30. Found: C, 56.25; H, 4.34; N 9.43. ${ }^{1} \mathrm{H}$ NMR (500 MHz, $\left.\mathrm{CDCl}_{3}\right): 2.34$ (s, 6H, $\mathrm{NMe}_{2}$ ), 2.79 (d, J= 12.9Hz, 1H, - $\left.\underline{\mathrm{H}}_{2}-\mathrm{NMe}_{2}\right), 3.58$ (d, J=12.9 Hz, 1H, $\left.-\underline{\mathrm{C}}_{2}-\mathrm{NMe}_{2}\right), 4.08-4.16$ (m, $\left.2 \mathrm{H},-\underline{\mathrm{C}}_{2}-\mathrm{NH}-\mathrm{Ar}\right), 4.61$ (t, J= 2.75Hz, 1H, Cp), 4.76-4.77 (m, 1H, Cp), 4.88 (m, 1H, Cp), 6.40 (s, $1 \mathrm{H}, \operatorname{Ar}), 7.35$ (d, J= 8.9Hz, 1H, Ar), 7.62 (d, J= 8.9Hz, 1H, Ar), 7.66-7.68 (m, 1H, NH), 7.97 (s, $1 \mathrm{H}, \mathrm{Ar}), 8.58$ (s, 1H, Ar). ${ }^{13} \mathrm{C}$ NMR $\left(500 \mathrm{MHz}, \mathrm{CDCl}_{3}\right): 40.2\left(\mathrm{NMe}_{2}\right), 45.2\left(-\mathrm{CH}_{2} \mathrm{NMe}_{2}\right), 56.0(-$ $\underline{\mathrm{CH}}_{2}$-NH-Ar, 79.1 (Cp), 85.1 (Cp), 85.7 (Cp), 100.1 (Cp), 101.20 (Cp), 100.3 (Ar), 118.4 (Ar), 122.2 (Ar), 122.3 (Ar), 125.5 (Ar), 128.7 (Ar), 132.1 (Ar), 135.3 (Ar), 150.3 (Ar). MSCI+ m/z (\%) : 455.1 (8), 454.1 (30), 453.2 (24), 452.2 (100), 418.2 (2), 274.1 (2), 54.8 (3). IR (solid) $v\left(\mathrm{~cm}^{-1}\right)$ : 632, 668, 807, 840, 1135, 1426, 1577, 1913, 1939 (strong, v $\mathrm{CO}$ ), 2011 (strong, $v_{\mathrm{CO}}$ ), 2831, 2950. IR in $\mathrm{CH}_{2} \mathrm{Cl}_{2}$ : v $\mathrm{CO}$ at $1934,2022 \mathrm{~cm}^{-1}$.

Compound 5. Aminomethylcymantrene 15 [37] (100 mg, $0.430 \mathrm{mmol}$, 1eq) was dissolved in 5 $\mathrm{mL}$ of dry, degassed, propanol and 7-chloro-4-fluoroquinoline (82 mg, $0.450 \mathrm{mmol}, 1.05 \mathrm{eq}$ ). The solution was refluxed under nitrogen overnight, after which the solvent was removed under reduced pressure and the compound purified by column chromatography over silica gel using AcOEt / hexanes (1:9) as the eluent. A light brown powder was obtained (113 mg, 67\%). Calcd 
for $\mathrm{C}_{18} \mathrm{H}_{12} \mathrm{ClMnN}_{2} \mathrm{O}_{3}$ : C, 54.78; H, 3.06; N, 7.10. Found: C, 55.35; H, 3.11; N 7.11. ${ }^{1} \mathrm{H}$ NMR $\left(500 \mathrm{MHz}, \mathrm{CDCl}_{3}\right): 4.23$ (s, 2H, - $\left.\underline{\mathrm{H}}_{2}-\mathrm{NH}-\mathrm{Ar}\right), 4.75$ (s, 2H, Cp), 4.91 (s, 2H, Cp), 5.43 (s, 1H, $\mathrm{NH}), 6.51-652(\mathrm{~m}, 1 \mathrm{H}), \mathrm{Ar}, 7.42(\mathrm{~d}, \mathrm{~J}=8.9 \mathrm{~Hz}, 1 \mathrm{H}, \mathrm{Ar}), 7.77$ (d, J=8.9Hz, 1H, Ar), 8.01 (s, 1H, Ar), 8.57-8.59 (m, 1H, Ar). ${ }^{13} \mathrm{C}$ NMR (500 MHz, $\left.\mathrm{CDCl}_{3}\right)$ : 40.6 (- $\left.\underline{C H}_{2}-\mathrm{NH}-\mathrm{Ar}\right), 82.1$ (Cp), 83.0 (Cp) , 99.2 (Ar), 101.2 (Cp), 116.9 (Ar), 120.9 (Ar), 125.9 (Ar), 128.5 (Ar), 135.4 (Ar), 148.7 (Ar), 149.2 (Ar), 151.5 (Ar). MSCI+ m/z (\%) : 397.8 (3), 396.8 (15), 395.9 (8), 394.8 (42), 346.8 (14), 297.0 (14), 254.9 (5), 224.9 (13), 224.0 (22), 223.0 (100). IR (neat) v(cm ${ }^{-1}$ ): 630, 664, 848, 1139, 1567, 1569, 1883, 1901, 1927 (strong, $v_{\mathrm{CO}}$ ), 2010 (strong, $v_{\mathrm{CO}}$ ). IR in $\mathrm{CH}_{2} \mathrm{Cl}_{2}$ : v $v_{\mathrm{CO}}$ at $1937,2022 \mathrm{~cm}^{-1}$.

Compound 6. $\alpha$-Formyl-(N,N,-dimethylaminomethyl)cymantrene 11 [37] (0.10g, 0.35 mmol) was dissolved in $5 \mathrm{~mL}$ dry methanol at $273 \mathrm{~K} . \mathrm{N}^{1}$-(7-chloroquinolin-4-yl)ethane-1,2-diamine $(0.084 \mathrm{~g}, 0.38 \mathrm{mmol})$ was added and the solution was refluxed for 5 hours before cooling to $273 \mathrm{~K}$. Sodium borohydride $(6.6 \mathrm{mg}, 0.17 \mathrm{mmol})$ was added and the solution was allowed to come back to room temperature. After $2 \mathrm{~h}$, most of the solvent was removed under reduced pressure and the mixture was dissolved in $10 \mathrm{~mL}$ dichloromethane. The solution was washed twice with $10 \mathrm{~mL}$ water, after which the organic layer was isolated, dried over magnesium sulfate, filtered, and evaporated under reduced pressure. The residue gave compound $\mathbf{6}$ as a light yellow solid $(0.10 \mathrm{~g}, 59 \%)$ after purification by column chromatography over silica gel using AcOEt/Hexane (1:9) as the eluent. ${ }^{1} \mathrm{H} \mathrm{NMR}\left(500 \mathrm{MHz}, \mathrm{CDCl}_{3}\right): 2.17$ (s, 6H, - $\left.\mathrm{NMe}_{2}\right), 2.65$ (m, J $\left.=12.9 \mathrm{~Hz}, 1 \mathrm{H},-\underline{\mathrm{C}}_{2}-\mathrm{NMe}_{2}\right), 2.09-3.10\left(\mathrm{~m}, 1 \mathrm{H}-\underline{\mathrm{C}}_{2}-\mathrm{NMe}_{2}\right), 3.20-3.40\left(\mathrm{~m}, 4 \mathrm{H},-\mathrm{CH}_{2}-\mathrm{CH}_{2}-\right.$ ) $3.58-3.66\left(\mathrm{~m}, 2 \mathrm{H},-\underline{\mathrm{C}}_{2}-\mathrm{NH}-\mathrm{Ar}\right), 4.57$ (t, J= 2.75 Hz, 1H, Cp), 4.68-4.70 (m, 1H, Cp), 4.73-475 (m, 1H, Cp), 5.87 (s, 1H, NH), 6.40 (s, 1H, Ar), 7.35 (d, J=8.7Hz, 1H, Ar), 7.72 (d, J=8.9Hz, 1H), 7.95 (s, 1H, Ar), 7.97 (s, 1H, Ar), 8.52 (s, 1H, Ar).

\subsection{Electrochemistry}

Electrochemical measurements were carried out using a PAR model 273 potentiostat interfaced through homemade software to a personal computer. Electrochemical measurements were performed using $0.05 \mathrm{M}\left[\mathrm{NBu}_{4}\right]\left[\mathrm{B}\left(\mathrm{C}_{6} \mathrm{~F}_{5}\right)_{4}\right] /$ dichloromethane electrolyte solutions from solvent that had been purified by passing it through an alumina-based purification system. Diamond-polished glassy carbon electrodes of $2 \mathrm{~mm}$ diameter were employed for cyclic voltammetry $(\mathrm{CV})$ scans. $\mathrm{CV}$ data were evaluated using standard diagnostic criteria for diffusion 
control and for chemical and electrochemical reversibility. The experimental reference electrode was a silver wire coated with anodically deposited silver chloride and separated from the working solution by a fine glass frit. The electrochemical potentials in this paper are referenced to the ferrocene/ferrocenium couple, as recommended elsewhere [38,39]. The ferrocene potential was obtained by its addition to the analyte solution [40] at an appropriate time in the experiment. Additional details on the electrochemical methodology are available in a previous paper [34].

\section{Results and Discussion}

\subsection{Synthesis}

Cymanquine (4) was synthesized in a four-step process following the preparation of the known compound $\alpha$-formyl-(N,N,-dimethylaminomethyl)-cymantrene 11 [37]. Scheme 1 gives the overall sequence beginning with commercially available cymantrene $\mathbf{8}$. Reduction of the formyl compound 11 with sodium borohydride gave the alcohol 12. The alcohol group was first

converted to a phthalimide by a Mitsunobu reaction, giving 13. A Gabriel type reaction was then employed to convert the phthalimide group to an amine, giving 14. Finally, coupling of the amino group in 14 to 7-chloro-4-fluoroquinoline [41] was carried out by a nucleophilic aromatic substitution, giving the desired final product, $\mathbf{4}$. IR spectra of $\mathbf{4}$ gave two carbonyl absorptions, indicating overlap of the asymmetric $v_{\mathrm{CO}}$ absorption. See experimental section for values in solid and solution. 
Scheme 1. Overall sequence for preparation of cymanquine, beginning with cymantrene.
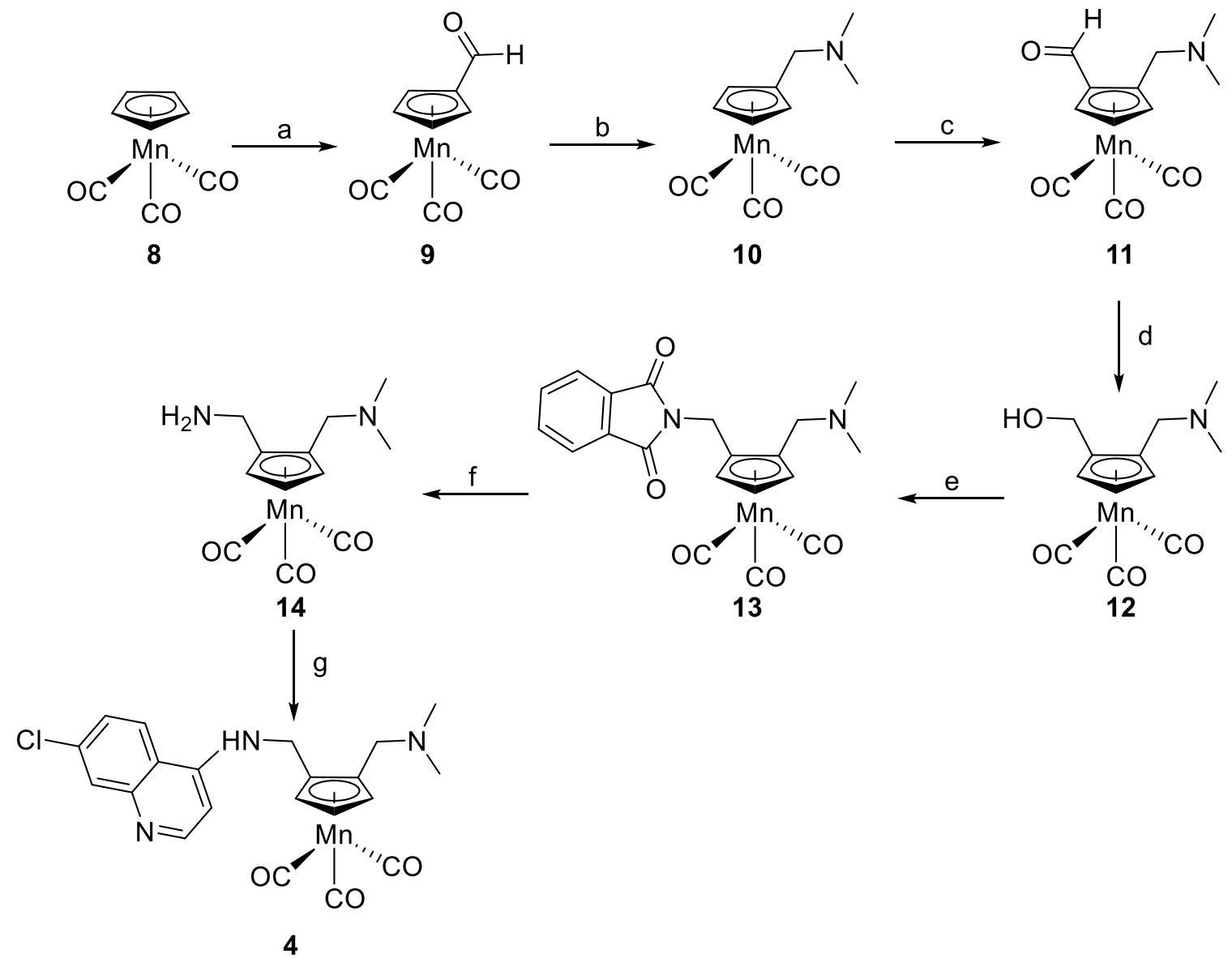

a) 1) 1.2 eq $n$-BuLi $1.6 \mathrm{M}$ in hexane, THF, $-78^{\circ} \mathrm{C}, 1 \mathrm{~h}$; 2) $1.5 \mathrm{eq} \mathrm{DMF}$, room temperature, $2 \mathrm{~h}$. b) 4 eq DMF + 5 eq $\mathrm{HCOOH}$, reflux, $4 \mathrm{~h}, 68 \%$ over two steps. c) 1) 1.5 eq $n$-BuLi $1.6 \mathrm{M}$ in hexane, THF, $-78^{\circ} \mathrm{C}, 1 \mathrm{~h}$; 2) 2 eq DMF, room temperature, 2h. d) 2 eq $\mathrm{NaBH}_{4}, \mathrm{MeOH}$, room temperature, $2 \mathrm{~h}, 67 \%$ over two steps. e) 1.3 eq $\mathrm{Ph}_{3} \mathrm{P}+1.3$ eq DIAD +1.3 eq phthalimide, THF, room temperature, 1h. f) 3 eq hydrazine hydrate, $\mathrm{MeOH}$, room temperature, $30 \mathrm{~min}$. g) 1.05 eq 7chloro-4-fluoroquinoline, propanol, reflux, $4 \mathrm{~h}, 32 \%$ over three steps.

A similar coupling reaction was employed to prepare 5. The known complex aminomethylcymantrene 15 was again coupled with 7-chloro-4-fluoroquinoline. 


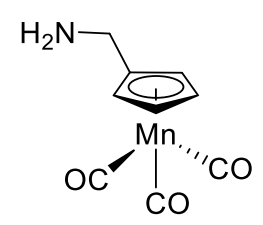

15

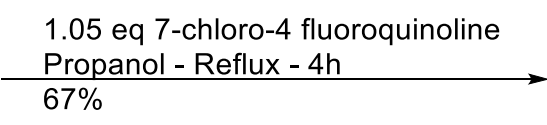

$67 \%$

IR spectra of $\mathbf{5}$ also gave two carbonyl absorptions, indicating overlap of the asymmetric $v_{\mathrm{CO}}$ absorption. See experimental section for values in solid and solution.

To obtain 6, $\alpha$-formyl-(N,N,-dimethylaminomethyl)-cymantrene 11 was condensed with $\mathrm{N}^{1}$ (7-chloroquinolin-4-yl)ethane-1,2-diamine [42] to form an imine, which was subsequently reduced by sodium borohydride. The analogous compound lacking a dimethylaminomethyl substituent on the $\mathrm{Cp}$ ring, 7, has been reported earlier [17].

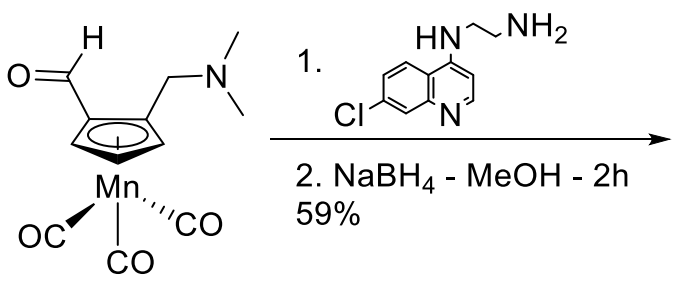

11

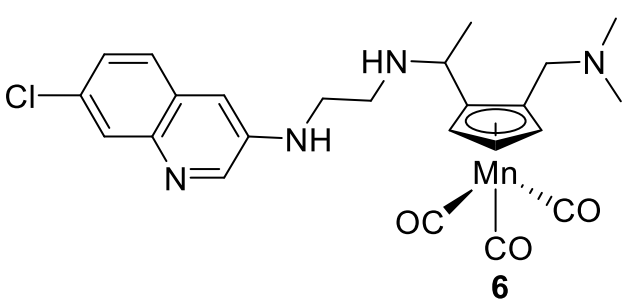

\subsection{Electrochemistry}

The anodic electrochemistry of compounds 4-6 was carried out in dichloromethane containing the weakly coordinating anion $\left[\mathrm{NBu}_{4}\right]\left[\mathrm{B}\left(\mathrm{C}_{6} \mathrm{~F}_{5}\right)_{4}\right](0.05 \mathrm{M})$ as supporting electrolyte. The advantages realized when positively-charged oxidation products, including the cymantrene radical cation [34], are generated in the presence of the "TFAB" anion, $\left[\mathrm{B}\left(\mathrm{C}_{6} \mathrm{~F}_{5}\right)_{4}\right]^{\text {", have been }}$ described in a number of papers [43-46]. In the present case, CV scans in dichloromethane/0.1 M $\left[\mathrm{NBu}_{4}\right]\left[\mathrm{PF}_{6}\right]$ solutions were impractical owing to electrode "history" and passivation effects caused by the precipitation of anodic reaction products on the electrode surface. These problems were minimized in the TFAB-based electrolyte, although occasional re-polishing of electrodes was required between scans.

Each of the three new compounds 4 - 6 exhibits two modestly-spaced, diffusion-controlled, anodic oxidations (see Figures 1 and 2) at the potentials collected in Table 1. The only 
chemically reversible process was that of the second oxidation of $5\left(E_{1 / 2}=1.35 \mathrm{~V}\right)$. That the redox reactions are one-electron processes was confirmed by bulk coulometry.

Table 1. Potentials vs ferrocene/ferrocenium in dichloromethane/0.05 $\mathrm{M}\left[\mathrm{NBu}_{4}\right]\left[\mathrm{B}\left(\mathrm{C}_{6} \mathrm{~F}_{5}\right)_{4}\right]$. The literature result for ferroquine (acetonitrile/0.1 $\mathrm{M}\left[\mathrm{NBu}_{4}\right]\left[\mathrm{ClO}_{4}\right]$ ) is included.

\begin{tabular}{|c|l|l|l|}
\hline Compound & First oxidation $^{\mathrm{a}}$ & Second oxidation $^{\mathrm{a}}$ & Source \\
\hline $\mathbf{4}(\mathrm{CMQ})$ & $\mathrm{E}_{\mathrm{pa}}=0.82 \mathrm{~V}$ & $\mathrm{E}_{\mathrm{pa}}=1.25 \mathrm{~V}$ & This work \\
\hline $\mathbf{5}$ & $\mathrm{E}_{\mathrm{pa}}=1.14 \mathrm{~V}$ & $\mathrm{E}_{1 / 2}=1.35 \mathrm{~V}$ & This work \\
\hline $\mathbf{6}$ & $\mathrm{E}_{\mathrm{pa}}=0.77 \mathrm{~V}$ & $\mathrm{E}_{\mathrm{pa}}=1.0 \mathrm{~V}$ & This work \\
\hline ferroquine $(\mathrm{FQ})$ & $\mathrm{E}_{1 / 2}=0.15 \mathrm{~V}$ & $\mathrm{E}_{\mathrm{pa}} \approx 0.79 \mathrm{~V}$ & Reference 49 \\
\hline $\mathrm{MnCp}(\mathrm{CO})_{3}$ (cymantrene) & $\mathrm{E}_{1 / 2}=0.92 \mathrm{~V}$ & n.a. & Reference 34 \\
\hline
\end{tabular}

${ }^{\mathrm{a}} \mathrm{E}_{\mathrm{pa}}$ values are given for scans at $0.2 \mathrm{~V} \mathrm{~s}^{-1}$.

Figure 1. Cyclic voltammetry scan of $1 \mathrm{mM}$ cymanquine (4) in dichloromethane/0.05 $\mathrm{M}$ $\left[\mathrm{NBu}_{4}\right]\left[\mathrm{B}\left(\mathrm{C}_{6} \mathrm{~F}_{5}\right)_{4}\right]$ at $2 \mathrm{~mm}$ glassy carbon electrode, scan rate $0.2 \mathrm{~V} \mathrm{~s}^{-1}$. 


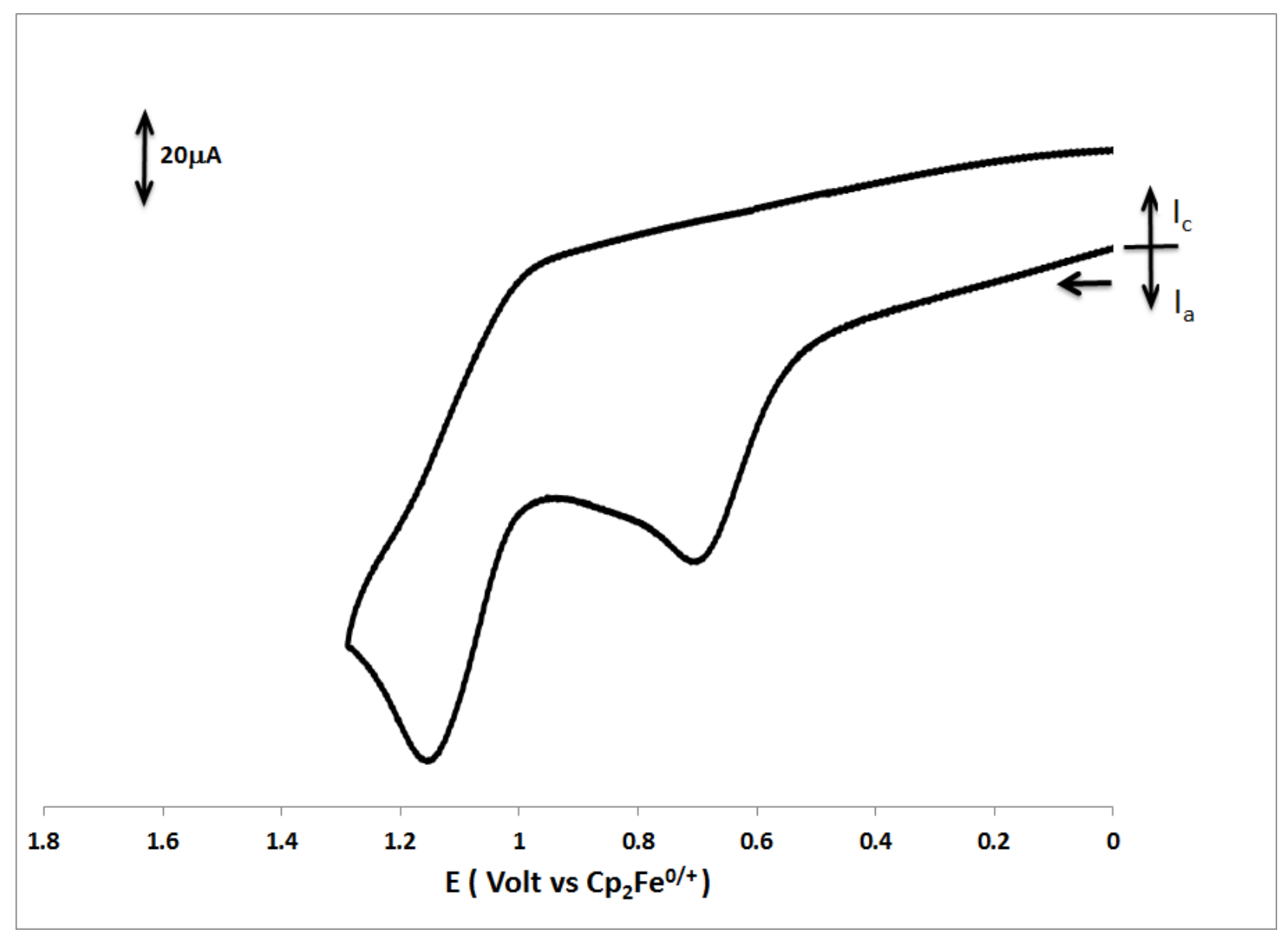

Figure 2. Cyclic voltammetry scan of $1 \mathrm{mM} 5$ in dichloromethane/0.05 $\mathrm{M}\left[\mathrm{NBu}_{4}\right]\left[\mathrm{B}\left(\mathrm{C}_{6} \mathrm{~F}_{5}\right)_{4}\right]$ at 2 mm glassy carbon electrode, scan rate $0.2 \mathrm{~V} \mathrm{~s}^{-1}$. 


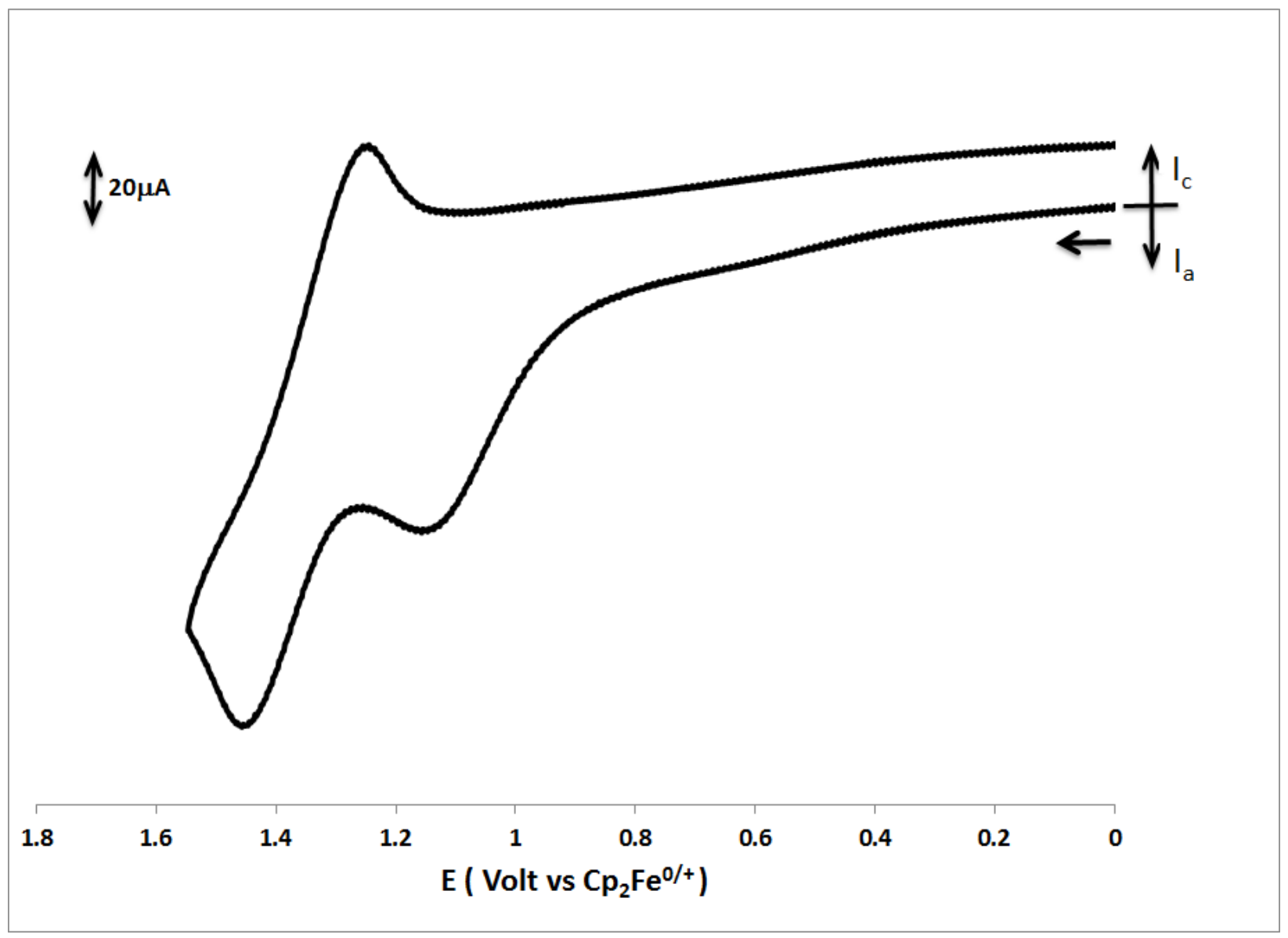

There are up to three possible electroactive groups in the compounds listed in Table 1: the organometallic moiety, one or more secondary amines in the linkage between the $\mathrm{Cp}$ ring and the chloroquine moiety, and a tertiary amine on a $\mathrm{Cp}$ ring. The oxidation of tertiary amines is usually found between $0.4 \mathrm{~V}$ and $0.8 \mathrm{~V}$ vs $\mathrm{FcH}$, whereas that of secondary amines comes at slightly more positive potentials $[47,48]$. For $F Q$, the first oxidation $\left(E_{1 / 2}=0.15 \mathrm{~V}\right)$ obviously occurs at the ferrocenyl group, as has been recognized [49]. A CV scan of FQ to more positive potentials (Figure 2 in reference 49) displayed a second anodic feature, poorly shaped and irreversible, at about $0.8 \mathrm{~V}$, which most likely arises from oxidation of ferroquine's tertiary amine group.

Assignment of the redox sites in CMQ cannot be done simply on the basis of the measured potentials, since the oxidation potential of a $\mathrm{MnCp}(\mathrm{CO})_{3}$ group is so much more positive than that of a FeCp 2 group ( $c a 0.9 \mathrm{~V}$, see Table). Specifically, the potential of the first oxidation of 4 $\left(\mathrm{E}_{\mathrm{pa}}=0.82 \mathrm{~V}\right)$ could be interpreted as being indicative of oxidation at either the manganese 
center or the tertiary amine group. However, an assignment of redox site can be made based on details of the reversibility of the anodic features. In all cases of which we are aware, the oxidations of simple aliphatic amines in nonaqueous solutions are chemically and electrochemically [50] irreversible [47, 48, 51]. This is not so for the oxidation of members of the $\mathrm{MnCp}(\mathrm{CO})_{3}$ family. There are certainly conditions under which the oxidation of a cymantrene group may not be fully chemically reversible owing to a follow-up reaction of the cymantrene radical cation [34]. However, this oxidation is not expected to be electrochemically irreversible owing to the fact that charge-transfer is fast in going from cymantrene to its radical cation. The experimental distinction between these two types of reversibilities is readily diagnosed by analysis of the shape of the anodic wave. With $\mathbf{4}$, as well as with $\mathbf{5}$ and $\mathbf{6}$, the first wave has the shape of a highly electrochemically irreversible process. The $E_{p}-E_{p / 2}$ value of $\mathbf{4}$ is $105 \mathrm{mV}$ at $\mathrm{v}=0.2 \mathrm{~V} \mathrm{~s}^{-1}$, diagnostic of a slow charge transfer process with a transfer coefficient $(\beta)$ of 0.45 [52]. Thus, there is little question that the initial oxidation of CMQ involves removal of an electron from the tertiary amine of the molecule. A similar analysis allows assignment of the second oxidation of $4\left(\mathrm{E}_{\mathrm{pa}}=1.25 \mathrm{~V}\right)$ to its secondary amine. Based on this assignment and the fact that additional anodic waves are not observed for $\mathbf{4}$ in scans out to the limit of the positive potential window, we conclude that oxidation of the manganese center of this molecule occurs at a potential greater than $1.9 \mathrm{~V}$ vs ferrocene.

The fact that compound $\mathbf{5}$ lacks a second aliphatic amine accounts for the fact that it demonstrates the only chemically reversible oxidation seen for the manganese compounds. Once again, the first oxidation $\left(\mathrm{E}_{\mathrm{pa}}=1.14 \mathrm{~V}\right)$ is highly irreversible, allowing its assignment to the 4amino position of the chloroquine unit. The breadth of this wave $\left(E_{p}-E_{p / 2}=125 \mathrm{mV}\right.$ at a scan rate of $0.2 \mathrm{~V} \mathrm{~s}^{-1}$ ) again suggests a totally irreversible process, with $\beta=0.4$ in this case. The second wave $\left(\mathrm{E}_{1 / 2}=1.35 \mathrm{~V}\right)$ has significant chemical reversibility, consistent with involvement of the manganese center in the second oxidation of $\mathbf{5}$.

The observation of two highly irreversible oxidations re-surfaces in the behavior of $\mathbf{6}$, which again has at least two oxidizable amines. Efforts are underway to fully characterize the products of the irreversible oxidations of both this group of cymantrene-tagged aminoquinoline compounds and the untagged ligand systems themselves. 


\section{Conclusions}

Three compounds have been prepared in which a 4-amino chloroquine group has been covalently linked to the cyclopentadienyl ring of a cymantrene moiety. One of them, which we term cymanquine (4), is the analogue of ferroquine, in which the FeCp group has been replaced by a $\mathrm{Mn}(\mathrm{CO})_{3}$ group. The new compounds exhibit a rich set of oxidative electrochemical reactions involving a sequence of either two amine-based oxidations (compounds $\mathbf{4}$ and $\mathbf{6}$ ) or an amine-based oxidation followed by oxidation of the cymantrene moiety (compound $\mathbf{5}$ ).

\section{Acknowledgements}

We thank the National Science Foundation (CHE-1212339) for partial support at the University of Vermont. We also thank Nazarbayev University (ORAU grant "Medicinal Electrochemistry - Development of New Tyrosine Kinase Inhibitors") for its support of this work.

\section{References}

1. G. Jaouen, A. Vessières, Transition metal carbonyl oestrogen receptor assay, Pure Appl. Chem. 57 (1985), 1865-1874.

2. C.G. Riordan, Bioorganometallic Chemistry, Dalton Trans., (2009) 4273. Themed issue, pp 4261-4384.

3. G. Jaouen (ed.), Bioorganometallics, Wiley-VCH, Weinheim, Germany, 2006.

4. E.A. Hillard, G. Jaouen, Bioorganometallics: Future Trends in Drug Discovery, Analytical Chemistry, and Catalysis, Organometallics 30 (2011) 20-27.

5. M. Navarro, W. Castro, C. Biot, Bioorganometallic Compounds with Antimalarial Targets: Inhibiting Hemozoin Formation, Organometallics 31 (2012) 5715-5727.

6. D.R. van Staveren, N. Metzler-Nolte, Bioorganometallic chemistry of ferrocene, Chem. Rev. 104 (2004) 5931-5985.

7. T.R. Johnson, B.E. Mann, J.E. Clark, R. Foresti, C.J. Green, R. Montterlini, Metal carbonyls: a new class of pharmaceuticals?, Angew. Chem. Int. Ed. 42 (2003) 3722- 3729.

8. H. Pfeiffer, A. Rojas, J. Niesel, U. Schatzschneider, Sonagashia and "click" reactions for the $\mathrm{N}$-terminal and side-chain functionalization of peptides with $\left[\mathrm{Mn}(\mathrm{CO})_{3}(\mathrm{tpm})\right]^{+}$-based carbonyl release molecules, Dalton Trans., (2009) 4292-4298. 
9. R. Arancibia, F. Dubar, B. Pradines, I. Forfar, D. Drive, A.H. Klahn, C. Biot, Synthesis and antimalarial activities of rhenium bioorganometallics based on the 4-aminoquinoline structure, Bioorganic and Medicinal Chemistry 18 (2010) 8085-8091.

10. M. Patra, G. Gasser, M. Wenzel, K. Merz, J.E. Bandow, N. Metzler-Nolte, Sandwich and half-sandwich derivatives of platensimycin: synthesis and biological evaluations, Organometallics 31 (2012) 5760-5771.

11. K. Meister, J. Niesel, U. Schatzschneider, N. Metzler-Nolte, D.A. Schmidt, M. Havenith, Label-free imaging of metal-carbonyl complexes in live cells by Raman spectroscopy, Angew. Chem. Int. Ed. 49 (2010) 3310-3312.

12. C. Policar, J. B. Waern, M-A. Plamont, S. Clède, C. Mayet, R. Prazeres, J-M. Ortega, A. Vessièeres, A. Dazzi, Subcellular IR imaging of a metal-carbonyl moiety using photothermallyinduced resonance, Angew. Chem. Int. Ed. 50 (2011) 860-864.

13. F. Le Bideau, A. Pérez-Luna, J. Marrot, M-N. Rager, E. Stéphan, S. Top, G. Jaouen, New and efficient synthesis of $\mathrm{CpRe}(\mathrm{CO})_{3}$ substituted steroids, Tetrahedron 57 (2001) 3939-3944.

14. M. Hromadová, M. Salmain, R. Sokolová, L. Pospíšil, G. Jaouen, Novel redox label for proteins. Electron transfer properties of $\left(\eta^{5}\right.$-cyclopentadienyl)tricarbonyl manganese bound to bovine serum albumin, J. Organometal. Chem. 668 (2003) 17-24.

15. B. Ferber, S. Top, A. Vessières, R. Welter, G. Jaouen, Synthesis of optically pure oformylcyclopentadienyl metal complexes of 17 $\alpha$-ethynylestradiol, Organometallics 25 (2006) 5730-5739.

16. K. Wu, S. Top, E.A. Hillard, G. Jaouen, W.E. Geiger, Anodic properties of diarylethene derivatives having organometallic piano-stool tags, Chem. Commun. (2011) 10109-10111.

17. L. Glans, W. Hu, C. Jöst, C. de Kock, P.J. Smith, M. Haukka, H. Bruhn, U. Schatzschneider, E. Norlander, Synthesis and biological activity of cymantrene and cyrhetrene 4-aminoquinoline conjugates against malaria, leishmaniasis, and trypanosomiasis, Dalton Trans 41 (2012) 64436450 .

18. C. Biot, W. Castro, C.Y. Botté, M. Navarro, The therapeutic potential of metal-based antimalarial agents: implications for the mechanism of action, Dalton Trans. 41 (2012) 63356349 .

19. L. Delhaes; F. B.-Vical, Francoise, D. Camus, M. Capron, B. Meunier, Chloroquine and artemisinin: six decades of research - what next?, Idrug, 6 (2003) 674-680. See also cdc.gov [online]. Available at: http://www.cdc.gov/malaria/resources.

20. I. Ben-Zvi, S. Kivity, P. Langevitz, Y. Shoenfeld, Hydroxychloroquine: from malaria to autoimmunity, Clinic Rev. Allerg. Immunol. 42 (2012), 145-153.

21. N.J. Olsen, M.A. Schleich, D.R. Karp, Multifaceted effects of hydroxychloroquine in human disease, Semin. Arthritis Rheum. 43 (2013) 264-272. 
22. P.B. Bloland, E.M. Lackritz, P.N. Kazembe, J.B. Were, R. Steketee, C.J. Campell, Beyond chloroquine: implications of drug resistance for evaluating malaria therapy efficiency and treatment policy in Africa, J. Infect. Dis. 167 (1993) 932-937.

23. V. Robert, H.P. Awono-Ambene, J.Y. Le Hesran, J.F. Trape, Gametocytemia and infectivity of mosquitoes of patients with uncomplicated $P$. falciparum malaria attacks treated with chloroquine or sulfadoxine plus pyromethamine, Amer. J. Trop. Med. Hygiene 62 (2000) 210216.

24. R. Pink, A. Hudson, M-A. Mouris, M. Bending, Opportunities and challenges in antiparasitic drug discovery, Nature Rev. Drug Discovery 4 (2005) 727-740.

25. C. Biot, G. Glorian, L. Maciejewski, J. Brocard, O. Domarle, G. Blampain, P. Millet, A.J.

Georges, H. Abessolo, D. Dive, J. Lebibi, Synthesis and antimalarial activity in vitro and in vivo of a new ferrocene-chloroquine analogue J. Med. Chem. 40 (1997) 3715-3718.

26. W. Daher, C. Biot, T. Fandeur, H. Jouin, L. Pelinski, E. Viscogliosi, L. Fraisse, B. Pradines, J. Brocard, J. Khalife, D. Dive, Assessment of Pasmodium falciparum resistance to ferroquine (SSR97193) in field isolates and in W2 strain under pressure, Malaria Journal 5 (2006), no pp given.

27. C. Biot, W. Daher, C.M. Ndiaye, P. Melnyk, B. Pradines, N. Chavain, A. Pellet, L. Fraisse, L. Pelinski, C. Jarry, J. Brocard, J. Khalife, I. Forfar-Bares, D. Dive, Probing the role of the covalent linkage of ferrocene into a chloroquine template, J. Med. Chem. 49 (2006) 4707-4714.

28. C. Biot, D. Dive, Bioorganometallic chemistry and malaria, Top. Organomet. Chem. 32 (2010) 155-193.

29. J. Marfut, F. Chalfein, P. Prayoga, F. Wabiser, E. Kenangalem, K.A. Piera, B. MacHunter, E. Tjitra, N.M. Anstey, R.N. Price, Ex vivo drug susceptibility of ferroquine against chlorquineresistant isolates of Plasmodium falciparum and P. vivax, Antimicrob. Chemother. 55 (2011) 4461-4464.

30. C.Y. Botté, F. Dubar, G.I. McFadden, E. Maréchal, C. Biot, Plasmodium falciparum Apicoplast drugs: targets or off-targets?, Chem. Rev. 112 (2012) 1269-1283.

31. P.F. Salas, C. Herrmann,J.F. Cawthray, C. Nimphius, A. Kenkel, J. Chen, C. de Kock, P.J. Smith, B.O. Patrick, M.J. Adam, C. Orvig, Structural characteristics of chloroquine-bridged ferrocenophane analogues of ferroquine may obviate malaria drug-resistance mechanisms, J. Med. Chem. 56 (2013) 1596-1613.

32. N. Chavain, V. Vezin, D. Dive, N. Touati, J-F. Paul, E. Buisine, C. Biot, Investigation of the redox behavior of ferroquine, a new antimalarial, Mol. Pharm. 5 (2008) 510-516.

33. F. Dubar, T.J. Egan, B. Pradines, D. Kuter, K. K. Ncokazi, D. Forge, J-F. Paul, C. Pierrot, H. Kalamou, J. Khalife, E. Buisine, C. Rogier, H. Vezin, I. Forfar, C. Slomianny, X. Trivelli, S. Kapishnikov, D. Dive, C. Biot, The antimalarial ferroquine: role of the metal and intramolecular hydrogen bond in activity and resistance, ACS Chem. Biol. 6 (2011) 275-287. 
34. D.R. Laws, D. Chong, K. Nash, A.L. Rheingold, W. E. Geiger, Cymantrene radical cation family: spectral and structural characterization of the half-sandwich analogues of ferrocenium ion, J. Am. Chem. Soc. 130 (2008), 9859-9870.

35. Patent applications have been filed by the authors for the use of cymanquine as an antimalarial and anticancer agent.

36. R.J. LeSuer, C. Buttolph, W.E. Geiger, Comparison of the conductivity properties of the tetrabutylammonium salt of tetrakis(pentafluorophenyl)borate anion with those of traditional supporting electrolyte anions in nonaqueous solvents, Anal. Chem. 76 (2004) 6395-6401.

37. N.M. Loim, N. A. Abramowa, Z.N. Parnes, D.N. Kursanow, Veränderung der orienterung in den metallierung-reaktion unter dem einfluss von isotopensubstitutiion, J. Organomet. Chem. 168 (1979) C33- C36.

38. G. Gritzner, J. Kuta, Recommendations on reporting electrode potentials in nonaqueous solvents , Pure Appl. Chem. 56 (1984) 461- 466.

39. N.G. Connelly, W.E. Geiger, Chemical redox agents for organometallic chemistry, Chem. Rev. 96 (1996), 877-910.

40. R.E. Gagne, C.A. Koval, G.C. Lisensky, Ferrocene as an internal standard for electrochemical measurements, Inorg. Chem. 19 (1980) 2854-2855.

41. M.V. Papadopoulou, M. Ji, M.K. Rao, W.D. Bloomer, 4-[3-(2-nitro-1imidazolyl)propylamino]-7-chloroquinoline hydrochloride (NLCQ-1), a novel bioreductive compound as a hypoxia-selective cytotoxin, Oncology Res. 12 (2001) 185-192.

42. N.I. Wenzel, N. Chavain, Y. Wang, W. Friebolin, L. Maes, B. Pradines, M. Lanzer, V. Yardley, R. Brun, C. Herold-Mende, C. Biot, K. Toth, E. Davioud-Charvet, Antimalarial versus cytotoxic properties of dual drugs derived from 4-aminoquinolines and Mannich bases: interaction with DNA, J. Med. Chem. 53 (2010) 3214-3226.

43. R.J. LeSuer, W.E. Geiger, Improved electrochemistry in low-polarity media using tetrakis(pentafluorophenyl)borate salts as supporting electrolytes, Angew. Chem. Int. Ed. 39 (2000) 248-250.

44. D. Chong, D.R. Laws, A. Nafady, P.J. Costa, A.L. Rheingold, M.J. Calhorda, W.E. Geiger, $\left[\operatorname{Re}\left(\eta^{5}-\mathrm{C}_{5} \mathrm{H}_{5}\right)(\mathrm{CO})_{3}\right]^{+}$family of 17 -electron compounds: monomer/dimer equilibria and other reactions, J. Am. Chem. Soc. 130 (2008) 2692-2703.

45. W.E. Geiger, F. Barriére, Organometallic electrochemistry based on electrolytes containing weakly-coordinating fluoroborate anions, Acc. Chem. Res. 43 (2010) 1030-1039.

46. K. Lam, W.E. Geiger, Anodic oxidation of disulfides: detection and reactions of disulfide radical cations, J. Org. Chem. 78 (2013) 8020-8027.

47. R.N. Adams, Electrochemistry at Solid Electrodes, Marcel Dekker, New York, 1969, pp. 375-377. 
48. C.K. Mann, Cylic stationary electrode voltammetry of some aliphatic amines, Anal. Chem. 36 (1964) 2424-2426.

49. M.A.L. Blackie, P. Beadley, K. Chibale, C. Clarkson, J.R. Moss, P.J. Smith, Synthesis and antimalarial activity in vitro of new heterobimetallic complexes: $\mathrm{Rh}$ and Au derivatives of chloroquine and a series of ferrocenyl-4-amino-7-chloroquinolines, J. Organometal. Chem. 688 (2003) 144-152.

50. In practical terms, electrochemical reversibility (also termed nernstian behavior) refers to the speed of charge-transfer in a redox reaction, whereas chemical reversibility refers to follow-up reactions that accompany the charge-transfer process. For an introductory discussion of these terms, see A.J. Bard, L.N. Faulkner, Electrochemical Methods, John Wiley \& Sons, New York, 2001, $2^{\text {nd }}$ Ed., pp 35-38 and pp 44-49.

51. O. Onomura in O. Hammerich, B. Speiser (Eds), Organic Electrochemistry, CRC Press, Boca Raton, 2016, $5^{\text {th }}$ Ed., pp 1103-1105.

52. See ref 50, p. 236. 


\section{Graphical Abstract}

Synthesis and Anodic Electrochemistry of Cymanquine and Related Complexes

Kevin Lam and William E. Geiger
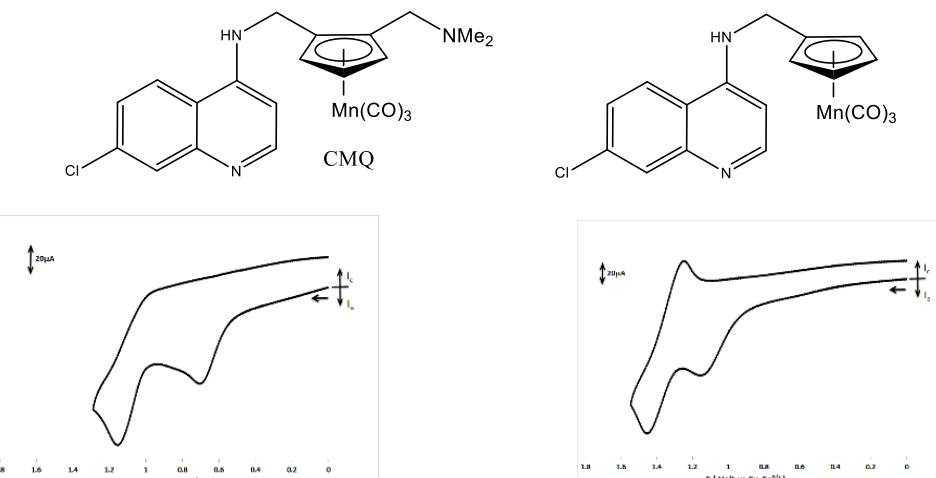

Synopsis: Cymanquine, a direct analogue of ferroquine, has been prepared, along with two other closely-related $\mathrm{MnCp}(\mathrm{CO})_{3} / 4$-aminochloroquinoline hybrid molecules. The most facile oxidation of the manganese compounds occurs at their aliphatic amine groups, rather than at the organometallic center. 